\title{
PENERAPAN ASAS KEPENTINGAN MILITER DAN PEMBERHENTIAN DENGAN TIDAK HORMAT TERHADAP PRAJURIT YANG TERLIBAT TINDAK PIDANA NARKOTIKA PADA PENGADILAN MILITER I-03/PADANG*
}

\author{
Hendra Mulyadi \\ Tentara Nasional Indonesia \\ Jl. Mh Thamrin No 5 Kec. Padang Timur Kota Padang \\ e-mail: gitamulyadi10@gmail.com com
}

\begin{abstract}
Abstrack
Former TNI Commander Gen. Gatot Nurmantio to clean up the Indonesian National Army Institution from the Narcotics influence has issued instructions and orders to his ranks, efforts to overcome the problem of narcotics are not separated from the Principles of Military Interest. The principle of military interests means that in carrying out state defense and security, military interests are prioritized more than the interests of groups and individuals. It means that in the judicial process, military interests are always balanced with legal interests, in enforcing the law, military interests must not be ignored. Law enforcers within the TNI in carrying out legal proceedings against narcotics abusers should not only see their legal interests, military interests but also must be seriously considered. Military Judges who will decide on Narcotics cases should not only see the problem from the law. The dismissal of soldiers who are perpetrators of narcotics abusers is very reasonable because from a medical point of view, someone who has consumed drugs is not ready to use, they will experience brain tissue damage, nerve cells and memory loss so that their physical condition is not prime anymore and will not be able to carry out basic tasks to the fullest. This writing aims at 1. To find out how the implementation/application of the principle of military interest in dismissal is disrespectful to the soldiers involved in narcotics crime 2. To find out how the judges' legal considerations apply the principle of military interest in dismissal with disrespect to the involved soldiers criminal narcotics, military court I-03 / Padang in practice has applied the principle of military interest in the consideration of penalties especially in narcotics criminal cases in its legal area both as a user and as a narcotics dealer, but has not been followed by orders to convicts to carry out medical rehabilitation.
\end{abstract}

Keywords: Military Interest Principles; Narcotics; Dismissal With Respect; Judge's Decision.

\begin{abstract}
Abstrak
Mantan Panglima TNI Jendral Gatot Nurmantio untuk membersihkan Institusi Tentara Nasional Indonesia dari pengaruh Narkotika telah mengeluarkan Instruksi dan perintah-perintah kepada jajarannya, upaya mengatasi permasalahan narkotika diiinstitusinya tidak lepas dari Asas Kepentingan Militer. Asas kepentingan militer mengandung arti bahwa dalam menyelenggarakan pertahanan dan keamanan negara, kepentingan militer diutamakan melebihi dari pada kepentingan golongan dan perorangan. Artinya bahwa dalam proses peradilan, kepentingan militer selalu diseimbangkan dengan kepentingan hukum, dalam menegakkan hukum, kepentingan militer tidak boleh diabaikan. Aparat penegak hukum di lingkungan TNI dalam melakukan proses hukum terhadap penyalahgunaan narkotika tidak boleh hanya melihat dari kepentingan hukumnya saja, kepentingan militer juga harus betul-betul dipertimbangkan. Hakim Militer yang akan memutus perkara-perkara Narkotika tidak boleh hanya melihat persoalan dari kaca mata undang-undang saja. Pemecatan terhadap prajurit pelaku tindak pidana penyalahguna narkotika sangatlah beralasan karena dari segi medis, seseorang yang telah mengkonsumsi narkoba tidak siap pakai, mereka akan mengalami kerusakan jaringan otak, sel-sel saraf dan penurunan daya ingat sehingga
\end{abstract}

\footnotetext{
* Naskah diterima: 16 Oktober 2018, direvisi: 28 Februari 2019, disetujui untuk terbit: 19 Maret 2019 Doi: $10.3376 /$ jch.v4i2.102
} 
kondisi fisiknya tidak prima lagi dan tidak akan mampu melaksanakan tugas pokok secara maksimal. Penulisan ini bertujuan 1. Untuk mengetahui bagaimanakah pelaksanaan/penerapan asas kepentingan militer dalam pemberhentian dengan tidak hormat terhadap Prajurit yang terlibat tindak pidana narkotika 2. Untuk mengetahui bagaimanakah pertimbangan hukum Majelis Hakim untuk menerapkan asas kepentingan militer dalam pemberhentian dengan tidak hormat terhadap Prajurit yang terlibat tindak pidana narkotika, Pengadilan militer I-03/Padang dalam prakteknya telah menerapkan asas kepentingan militer pada pertimbangan hukuman khususnya dalam kasuskasus tindak pidana narkotika diwilayah hukumnya baik hanya sebagai pemakai maupun sebagai pengedar narkotika, namun belum diikuti dengan perintah terhadap terpidana untuk melaksanakan rehabilitasi medis.

Kata Kunci: Asas Kepentingan Militer; Narkotika; Pemberhentiaan Dengan Tidak Hormat; Putusan Hakim.

\section{PENDAHULUAN}

Sampai saat ini belum ada literatur yang lengkap mengenai hasil penelitian tentang penerapan asas kepentingan militer terhadap prajurit yang terlibat narkotika dan berujung dengan pemberhentian dengan tidak hormat dari dinas militer. Institusi Tentara Nasional Indonesia dibangun dan dikembangkan dengan cara membentuk tentara yang profesional sesuai dengan kepentingan politik negara Indonesia, Tentara merupakan bagian dari masyarakat yang dipersiapkan secara khusus untuk melaksanakan tugas pembelaan negara terhadap ancaman dari negara lain, pasal 5 UU TNI dijelaskan Tentara Nasional Indonesia berperan sebagai alat negara dibidang pertahanan yang menjalankan tugasnya berdasarkan kebijakan dan keputusan politik Negara, selain itu Tentara nasional Indonesia merupakan kekuatan utama dan rakyat sebagai kekuatan pendukung.

Pasal 7 ayat (1) Undang-Undang Nomor 34 tahun 2004 tentang Tentara Nasional Indonesia Tugas pokok TNI adalah menegakkan kedaulatan negara, mempertahankan keutuhan wilayah NKRI yang berdasarkan Pancasila dan Undangundang Dasar Negara Republik Indonesia Tahun 1945 serta melindungi segenap bangsa dan seluruh tumpah darah Indonesia dari ancaman dan gangguan terhadap keutuhan bangsa dan negara.

Presiden Republik Indonesia Ir. Joko Widodo menyatakan Indonesia sedang dalam "Darurat Narkoba". Penyalahgunaan narkotika dan obatobatan terlarang di kalangan generasi muda dewasa ini kian meningkat, maraknya penyimpangan perilaku generasi muda tersebut dapat membahayakan keberlangsungan hidup bangsa ini di kemudian hari, pemuda sebagai generasi yang diharapkan menjadi penerus bangsa semakin hari semakin rapuh digerogoti zat-zat adiktif penghancur syaraf sehingga pemuda tersebut tidak dapat berpikir jernih akibatnya generasi harapan bangsa yang tangguh dan cerdas hanya akan tinggal kenangan. Sasaran dari penyebaran narkoba ini adalah kaum muda atau remaja kalau dirata-ratakan usia sasaran narkoba ini adalah usia pelajar berkisar umur 11 sampai 24 tahun. Hal tersebut mengindikasikan bahwa bahaya narkoba 
sewaktu-waktu dapat mengincar anakanak kita kapan saja, bahaya penyalahgunaannya tidak hanya terbatas pada diri pengguna, pecandu, maupun pengedar, bahkan dapat membawa akibat lebih jauh lagi yaitu gangguan terhadap tata kehidupan masyarakat yang bisa berdampak pada malapetaka runtuhnya suatu bangsa negara didunia.

Dalam melaksanakan tugas dan fungsinya adanya beberapa persoalan hukum pada pembinaan prajurit dan sangat mendesak saat ini serta harus segera diatasi salah satunya penegakan hukum dibidang narkotika dilingkungan prajurit, masalah ini sangat diperlukan penanganan secara khusus bila dibandingkan dengan penyelesaian tindak pidana Narkotika yang dilakukan oleh warga sipil.

Sebagai bukti keseriusan pemerintah Indonesia dalam menanggulangi penyalahgunaan narkotika tersebut telah diwujudkan dengan dikeluarkannya Undang-Undang Nomor 9 Tahun 1976 tentang Narkotika dan telah diperbaharui dengan Undang-Undang Nomor 35 tahun 2009 dan juga bentuk keseriusan TNI untuk mengatasikan dampak kejahatan narkotika dikalangan prajurit TNI mendapat perhatian sangat serius dari Pimpinan TNI.

Badan Narkotika Nasional telah merilis data terbaru kasus penyalahgunaan narkotika di Indonesia selama Januari hingga Juni 2017, didunia terdapat 812 jenis narkoba, 65 jenis narkoba yang dikonsumsi pengguna narkoba di Indonesia dan baru 43 jenis sudah terdaftar dan 22 belum terdaftar. BNN berhasil mengungkap 46,537 kasus narkoba dan menetapkan setidaknya 58.365 tersangka (okezone.com). Badan Narkotika Nasional Provinsi (BNNP) Sumatera Barat mencatat penyalahguna narkoba mencapai 63.352 jiwa dan menempati urutan ke-24 dari 33 propinsi di Indonesia 63 ribu penduduk provinsi itu menyalahgunakan narkoba baik jenis ganja kering, pil ekstasi maupun sabusabu. "Angka pengguna narkoba ini mengalami kenaikan sekitar lima persen dari tahun 2016, yakni sekitar 59 ribu orang," kata Kepala BNNP Sumbar Brigjen Pol Syamsul Bahri saat memberikan sambutan dalan peringatan Hari Anti Narkoba Internasional (Mario Sofia, 2017).

Staf Pengamanan Angkatan Darart (Spamad) mencatat 109 Kasus narkoba melibatkan 123 personil AD terjadi selama tahun 2017 (Spmad, 2017), sedangkan kasus Narkotika di wilayah hukum Pengadilan Militer I/03 Padang pada tahun 2015 sebanyak 18 kasus dipecat 15, bebas 3 kasus, tahun 2016 sebanyak 20 kasus dipecat 19 kasus, bebas 1 kasus, tahun 2017 sebanyak 21 kasus, dipecat 17 kasus bebas 4 kasus diantaranya (Dilmil I-03, 2017).

Mantan Panglima Tentara Nasional Indonesia Jendral Gatot Nurmantio menjelaskan dalam rapat pimpinan Tentara Nasional Indonesia pada awal tahun 2018 berdasarkan data pelanggaran prajurit dilingkungan TNI pelanggaran tindak pidana narkotika menujukan rangking Ke 2 (dua) setelah Desersi dan 
THTI sehingga beliau sangat serius untuk membersihkan Institusi TNI dari pengaruh Narkotika dengan mengeluarkan Instruksi dan perintahperintah kepada jajaran TNI bahwa setiap prajurit TNI yang terlibat narkotika disamping dihukum pidana harus dijatuhi hukuman tambahan pemberhentian secara tidak hormat dari dinas keprajuritan dan tidak berlakukanya rehablitasi bagi prajurit (liputan6.com), perintah dan instruksi Panglima TNI dalam upaya mengatasi permasalahan narkotika diinstitusinya tersebut tidak lepas dari Asas Kepentingan Militer.

Asas Kepentingan Militer diatur dalam penjelasan umum Undang-Undang Nomor 31 Tahun 1997 tentang Peradilan Militer disebutkan ada 3 (tiga) asas dalam peradilan Militer (Iman Syahputra Putra Tunggal, 1999):

1. Asas kesatuan komando.

2. Asas komandan bertanggung jawab terhadap anak buahnya.

3. Asas kepentingan militer.

Untuk menyelenggarakan pertahanan dan keamanan negara, kepentingan militer diutamakan melebihi dari pada kepentingan golongan dan perorangan. Namun, khusus dalam proses peradilan kepentingan militer selalu diseimbangkan dengan kepentingan hukum. Artinya bahwa dalam proses peradilan, kepentingan militer selalu diseimbangkan dengan kepentingan hukum, dalam menegakkan hukum, kepentingan militer tidak boleh diabaikan.
Sehubungan dengan judul penerapan Asas Kepentingan Militer dalam pemberhentian dengan tidak hormat terhadap Prajurit TNI yang terlibat tindak pidana Narkotika (studi kasus dipengadilan Militer I-03/Padang), maka dapat dirumuskan permasalahan dengan mengajukan pertanyaan sebagai berikut: Bagaimanakah penerapan Asas Kepentingan Militer dalam pemberhentian dengan tidak hormat (PDTH) terhadap Prajurit TNI yang terlibat tindak pidana narkotika (studi kasus dipengadilan militer I-03/Padang). Apakah pertimbangan hakim dalam putusannya untuk menerapkan asas kepentingan militer dalam pemberhentian dengan tidak hormat terhadap Prajurit TNI yang terlibat tindak pidana narkotika (studi kasus dipengadilan militer I03/Padang).

\section{METODE PENELITIAN}

Pendekatan yang digunakan dalam penelitian ini adalah metode pendekatan yang bersifat empiris (yuridis sosiologis). Jenis data penelitian ini adalah Data primer meliputi data yang diperoleh langsung di lapangan yang berkaitan dengan putusan-putusan hakim Militer yang berhubungan dengan kasus Narkotika wilayah hukum Peradilan Militer I-03/Padang. Data sekunder meliputi peraturan perundang-undangan, peraturan-peraturan interen TNI, pendapat para pakar hukum pidana dan hukum acara pidana, serta bahan-bahan kepustakaan lainnya.

Sumber data penelitian ini adalah: penelitian kepustakaan (libbrary 
research) dan studi lapangan (field researh). Teknik pengumpulan data dalam penelitian ini dengan meneliti beberapa putusan-putusan hakim Militer yang berhubungan dengan kasus Narkotika wilayah hukum Peradilan Militer I-03/Padang (Bambang Sunggono, 2003).

\section{HASIL DAN PEMBAHASAN}

\section{Penerapan Asas Kepentingan Militer oleh Majelis}

Kalau kita pelajari hampir semua kasus narkotika yang sudah diputus bersalah oleh Pengadilan Militer di Indonesia dan khususnya Pengadilan Militer I-03/Padang sudah dapat dipastikan bahwa selalu diikuti dengan penambahan hukuman tambahan yaitu berupa pemberhentian dengan tidak hormat dari dinas militer hal ini dapat kita lihat dari laporan tahunan 201518 kasus dipecat 15, tahun 201620 kasus dipecat 19 dan tahun 201721 kasus dipecat 17 kasus. Hal ini semua tidak terlepas dari bentuk penegakan hukum yang bersifat lex specialis, artinya mengunakan Undang-undang dan hukum acara tersendiri.

Pemberhentian dengan tidak hormat ini merupakan penyimpangan dari asasasas hukum pidana umum, antara lain mengenai sanksi pidana. Bentuk penyimpangan hukum pidana dalam KUHPM dapat diilihat dalam pasal 6 huruf b ke-1 KUHPM yang menyatakan bahwa salah satu jenis hukum pidana tambahan, pemecatan ini bersifat murni kemiliteran (Van zuiver militaire aard) yang tidak ada dalam hukum pidana umum (KUHP). Pasal 6 huruf b ke-1 KUHPM, menyatakan; "Pidana tambahan dipecat dari Dinas Militer dengan atau tanpa pencabutan haknya untuk memasuki Angkatan Bersenjata".

Pasal 6 KUHPM juga menentukan jenis-jenis pidana:

a) Pidana utama (pokok):

ke-1 pidana mati;

ke-2 pidana penjara ;

ke-3 pidana kurungan ;

ke-4 pidana tutupan (UndangUndang No. 20 tahun 1946)

b) Pidana-pidana tambahan:

ke-1Pemecatan dari dinas militer dengan atau tanpa pencabutan haknya untuk memasuki Angkatan Bersenjata

ke-2Penurunan pangkat ;

ke-3Pencabutan hak-hak yang disebutkan pada Pasal 35 ayat pertama pada nomor ke-1, ke-2 dan ke-3 KUHP.

Pasal 26 KUHPM, menyatakan;

"Pemecatan dari dinas Militer dengan atau tanpa pencabutan hak untuk memasuki Angkatan Bersenjata, selain dari pada ditentukan dalam pasal 39, dapat dijatuhkan oleh Hakim berbarengan dengan setiap putusan penjatuhan pidana mati atau pidana penjara kepada seseorang Militer yang berdasarkan kejahatan yang dilakukan di pandangnya tidak layak lagi tetap dalam kalangan Militer.

Pasal 53 ayat (1) dan ayat (2) Peraturan Pemerintah Republik Indonesia Nomor 39 Tahun $2010 \quad$ Tentang Administrasi Prajurit TNI menyatakan. 
"Prajurit diberhentikan tidak dengan hormat dari Dinas Keprajuritan karena:

(1) Dijatuhi pidana tambahan dipecat dari dinas militer berdasarkan putusan pengadilan yang telah memperoleh kekuatan hukum tetap; atau

(2) Mempunyai tabiat dan/atau perbuatan yang nyata-nyata dapat merugikan disiplin keprajuritan atau TNI.

Pada prinsipnya pemberhentian seorang prajurit dilingkungan TNI dapat dilakukan melalui 3 (tiga) jalur atau saluran :

1. Hukum Administrasi

2. Hukum Disiplin Prajurit.

3. Keputusan Pengadilan Militer.

Tiga cara ini diatur oleh Peraturan Pemerintah Nomor 39 Tahun 2010 Tentang Administrasi Prajurit.

Bahwa penjatuhan pidana tambahan pemecatan (PDTH) juga harus memperhatikan ketentuan pasal 5 ayat (1) Undang-Undang Nomor 31 Tahun 1997 tentang Peradilan Militer "Peradilan Militer merupakan pelaksanaan kekuasaan kehakiman di lingkungan TNI untuk menegakkan hukum dan keadilan dengan memperhatikan kepentingan penyelenggaraan pertahanan keamanan negara, di penjelasan pasal dipertegas lagi”.

Untuk menyelenggarakan pertahanan dan keamanan negara maka kepentingan militer diutamakan melebihi dari pada kepentingan golongan dan perorangan. Aparat penegak hukum di lingkungan TNI dalam melakukan proses hukum terhadap penyalahguna narkotika tidak boleh hanya melihat dari kepentingan hukumnya saja, kepentingan militer juga harus betul-betul dipertimbangkan. Hakim Militer yang akan memutus perkaraperkara narkotika tidak boleh hanya melihat persoalan dari kaca mata undangundang, para hakim militer juga harus selalu mempertimbangkan kepentingan militer dalam putusannya, disinilah letak salah satu kekhususan Hukum militer dengan berbagai peraturan yang khusus, tuntutan untuk memecat Prajurit yang terlibat narkoba seyogianya janganlah dimaknai sebagai bentuk intervensi pimpinan TNI terhadap proses peradilan. Ini hanya semata-mata dilakukan untuk menjaga tetap tegaknya asas kepentingan militer dalam penegakan hukum sebagaimana telah diamanatkan oleh Undang-Undang sendiri, dalam hal ini Panglima TNI memiliki kepentingan strategis untuk memperjuangkan asas kepentingan militer dalam proses peradilan agar kepentingan penegakan hukum berjalan seimbang dan seirama dengan kepentingan pertahanan negara. Terhadap kasus narkotika ada beberapa pertimbangan strategis dan kepentingan pembinaan personil TNI guna mempersiapkan satuan TNI siap digerakan kapan dan dimana saja, tidak mudah untuk mencapai hal tersebut dibutuhkan prajurit TNI yang sehat jasmani maupun rohaninya dan dilatih fisik maupun mentalnya hingga mahir dibidangnya (profesional), tentunya akan didapat melalui pendidikan dan latihan, pendidikan dan tugas TNI tidak terlepas dari senjata dan alat tempur lainnya, 
prajurit TNI yang telah terpengaruh dengan narkotika maupun physikotropika sudah jelas dan pasti tidak akan dapat melaksanakan pendidikan dan latihan serta tugas dengan baik atau maksimal, dapat dibayangkan apa yang akan terjadi bila seorang prajurit TNI sedang terpengaruh dengan narkotika memegang senjata ? dapat dipastikan kalau tidak dirinya sendiri atau orang lain akan terluka menjadi korban, bila dilihat dari keberhasilan suatu operasi militer tentunya kan mengacaukan jalannya suatu operasi militer. Bila hal ini dibiarkan tentunya akan merugikan militer itu sendiri. Aspek-aspek inilah yang menjadi salah satu pertimbangan majelis hakim militer dalam penjatuhan hukuman terhadap prajurit TNI pengedar maupun pemakai narkotika.

Dari penelitian yang penulis teliti dapat dilaporkan bahwa majelis hakim pengadilan militer I-03/Padang untuk menerapkan Asas Kepentingan Militer Terhadap Prajurit TNI yang terlibat tindak pidana Narkotika dan Pysikotropika, sudah dilaksanakan sebagaimana mestinya sehingga didalam putusannya majelis memuat dalam pertimbangan hukumnya dapat diambil contoh dalam perkara. Perkara Nomor: 22-K/PM I03/AD///2018 tanggal 14 Mei 2018, Perkara Nomor: 05-K/PM I-03/AD/I/2018 tanggal 24 Januari 2018, Perkara Nomor: 123-K/PM.I-03/AD/XII/2017 pada inti

Menimbang :

a. Bahwa perbuatan terdakwa ini dapat membahayakan generasi muda Indonesia dan apabila dibiarkan maka akan berpengaruh besar terhadap keamanan dan kelangsungan umat manusia khusus di Negara Kesatuan Republik Indonesia.

b. Bahwa perbuatan Terdakwa ini sangat bertentangan dengan program pemerintah dalam pemberantasan narkotika.

c. Bahwa perbuatan Terdakwa ini juga sangat bertentangan dengan cita-cita dan keinginan dari Panglima TNI dalam membantu pemerintah memberantas narkotika dan juga prajurit TNI khususnya bersih serta terbebas dari pengaruh narkotika.

d. Bahwa perbuatan terdakwa ini merupakan salah satu dosa besar yang tidak dapat diampuni apabila dilakukan oleh seorang prajurit TNI karena sangat berbahaya bagi prajurit TNI lainnya apabila hal serta berpengaruh besar dalam pelaksanaan tugas sebagai prajurit TNI.

e. Bahwa program pemerintah dalam upaya pemberantasan dan peredaran serta penyalahgunaan narkotika sangat serius dilakukan karena halhal yang berkaitan dengan narkotika yang dilakukan secara tanpa izin oleh lembaga dan pejabat maupun instansi yang berwenang sangat merusak mental dan fisik generasi muda oleh karena itu terhadap para pelaku termasuk diri Terdakwa harus ditindak tegas.

f. Bahwa di lingkungan TNI program pemerintah dalam pemberantasan tindak pidana peredaran dan penyalahgunaan narkotika tersebut ditindaklanjuti oleh pemimpin TNI 
dengan dikeluarkannya ST Panglima TNI tentang 7 (tujuh) jenis tindak pidana yang harus dihindari atau yang sangat dilarang dilakukan oleh prajurit TNI, diantara lain tentang peredaran dan penyalahgunaan narkotika tersebut.

g. Bahwa sesuai fakta di persidangan Terdakwa pada tahun 2009 saat dinas di Lanal Lhoksuemawe Aceh sudah pernah dijatuhi hukuman pidana penjara selama 6 (enam) bulan dan setelah melaksanakan hukuman tersebut Terdakwa kembali dijatuhi hukuman pidana penjara selama 6 (enam) bulan dalam perkara asusila.

h. Bahwa terhadap perbuatan Terdakwa mengkonsumsi sabu-sabu maupun terhadap perkara asusila, mengindikasikan Terdakwa tidak peduli dengan berbagai aturan hukum yang diatur secara khusus maupun secara umum termasuk di lingkungan TNI sehingga mengindikasikan Terdakwa tidak berupaya untuk memperbaiki diri serta tidak merasa jera dan hal itu sangat bertentangan dengan disiplin serta tata tertib dalam kehidupan prajurit dan mencemarkan nama baik TNI khususnya kesatuan Terdakwa.

Bahwa berdasarkan alasan tersebut diatas, kami berpendapat bahwa majelis hakim pengadilan militer I-03/Padang telah menerapkan asas kepentingan militer dengan benar secara implisit yang dimuat pada bagian pertimbangan hukumnya dan jelas element-element dari asas kepentingan militer dimaksud sudah tercermin, tergambar serta termuat dalam pertimbangan majelis hakim.

\section{Pertimbangan Majelis Dalam Memerapkan Asas Dan \\ Pemberhentian Dengan Tidak Hormat.}

Seperti uraian penulis sebelumnya bahwa penyalahgunaan Narkotika di kalangan umum maupun militer telah mewabah dan sangat mekhwatirkan apalagi dikalangan prajurit, prajurit yang merupakan garda terdepan dalam mempertahankan kedaulatan negara Kesatuan Republik Indonesia dari sabang sampai Merauke untuk mengatasinya keadaan ini Panglima TNI sudah memberikan arahan dan petunjuk kepada para instansi terkait yang berwenang untuk menyelesaikan perkara narkotika terhadap prajurit TNI, serta dalam hal ini Babinkum TNI, Direktorat Hukum Angkatan Darat, Dinas Hukum Angkatan Laut, dan Dinas Hukum Angkatan Udara serta jajaran Peradilan Militer dibawah Mahkamah Agung Republik Indonesia. begitu juga Peradilan Militer I-03/Padang "apabila prajurit TNI terbukti mengunakan, pengedar atau terlibat dengan masalah narkotika dan dipersidangan dinyatakan bersalah oleh majelis hakim maka terhadap Yang bersangkutan dijatuhi hukuman penjara dan hukuman tambahan pemecatan dari dinas TNI (PDTH) supaya menjadai efek jera terhadap prajurit lainnya". Dari data yang ada sudah ratusan bahkan lebih prajurit TNI dipecat karena terbukti menggunakan, jadi kurir bahkan jadi bandar namun pelanggar narkotika masih 
juga ada bahkan meningkat, timbul pertanyaan bagaimana kalau prajurit pelanggar kasus narkotika tidak dipecat tentunya pelanggar-pelanggar narkotika lainnya lebih meninggkat lagi, hal ini sangat membahyakan kepentingan militer kedepannya.

Seperti telah disampaikan terdahulu bahwa mengenai eksistensi hukum pada pemecatan (PDTH), tidak satu pasalpun didalam KUHPM mencamtumkan secara eksplisit mengenai syarat-syarat yang harus dipenuhi dan dipertimbangkan oleh majelis hakim. Pasal 26 (1) KUHPM hanya menyatakan bahwa pemecatan dapat dilakukan oleh hakim terhadap militer apabila dipandang tidak layak lagi untuk dipertahankan untuk berdinas militer, mengenai persyaratan untuk layak dan tidak layanya untuk tetap berdinas militer yang dijadikan sebagai dasar pertimbangan hakim dalam menjatuhkan pidana tambahan pemecatan tidak diterangkan dalam KUHPM namun diserahkan sepenuhnya kepada penilaian majelis hakim, walaupun KUHPM maupun peraturan lainnya tidak menerangkan tentang kretaria layak tidaknya akan tetapi majelis hakim sudah memahami dan memaknai subtansi dari layak atau tidaknya seorang prajurit yang terlibat narkotika untuk tetap dipertahan atau tidak lagi berdinas dilingkungan TNI (Pecat/PDTH).

Makna layak dan tidak layak (ongeshikt) sebagai dasar oleh hakim dalam menjatuhkan pidana tambahan bahwa sudah tidak atau sangat kurang menpunyai sifat-sifat yang seharusnya dimiliki oleh seorang prajurit, serta dinilai akan membahayakan institusi TNI maupun prajurit lainnya, disinilah makna kepentingan militer yang harus dijaga dan pertimbangkan, makna layak tidak layaknya seorang parajurit TNI tetap dipertahankan atau tidak berdinas dilingkungan TNI bukan hanya dikarenakan prajurit terpidana tidak mempunyai kemampuan atau kecakapan (onbekwaam) untuk menjalankan kedinasan dimiliter semata akan tetapi pidana tambahan pemecatan terhadap militer oleh hakim militer harus tercakup dan tersirat dalam pertimbangan hukum putusan hakim dan hal paling essensial apabila dalam pertimbangan hukum hakim militer tidak dijatuhkan pidana tambahan pemecatan maka kehadiran terpidana nantinya dalam kalangan militer setelah selesai menjalankan pidana akan menggoyahkan sendi-sendi ketertiban dalam masyarakat militer. penambahan hukuman tambahan berupa pemberhentian dari dinas militer yang merupakan penyimpangan dari asas-asas hukum pidana umum, antara lain mengenai sanksi pidana.

Bentuk penyimpangan hukum pidana dalam KUHPM dapat dilihat dalam pasal 6 huruf b ke-1 KUHPM yang menyatakan bahwa salah satu jenis hukum pidana tambahan, pemecatan ini bersifat murni kemiliteran (Van zuiver militaire aard) yang tidak ada dalam hukum pidana umum (KUHP). Majelis hakim dalam menerapkan pemberhentian dengan tidak hormat kasus narkotika dipengadilan Militer I-03/Padang tidak menemui 
kendala yang berarti, majelis pengadilan militer I-03/Padang dalam menerapkan pemberhentian dengan tidak hormat dari dinas TNI (pecat) secara jelas (eksplisit) memuat pada pertimbangannya majelis hakim pada saat menerapkannya selalu mempertimbangkan berdasarkan asas kepentingan militer dan segala aspekaspek lainnya serta masukan-masukan termasuk dari pemimpin TNI, serta rekomendasi/masukan dari kesatuan sepanjang dapat diterima dan tidak melanggar peraturan-peraturan yang ada. Hal-hal tersebut bukanlah merupakan bentuk intervensi pemimpin TNI maupun kesatuan terhadap indenpendensi peradilan militer melainkan dalam rangka menerapkan Undang-undang, aturanaturan yang berlaku umum maupun diberlakukan secara khusus terutama mengenai asas kepentingan militer dan pemberhentian dengan tidak hormat dalam kasus tindak pidana narkotika.

Dari hasil penelitian penulis diPengadilan Militer I-03/Padang tentang Pemberhentian dengan tidak hormat terhadap prajurit TNI yang terbukti bersalah melakukan tindak pidana narkotika baik sebagai pemakai, pecandu apalagi pengedar narkotika sudah dapat diterapkan dengan baik, hal ini dapat kita lihat dari berbagai putusan yang dikeluarkan oleh pengadilan militer I03/Padang Perkara Nomor: 22-K/PM I03/AD/I/2018 tanggal 14 Mei 2018, Perkara No 05-K/PM I-03/AD/I/2018 tanggal 24 Januari 2018, Perkara No 123K/PM.I-03/AD/XII/2017 semuanya berujung kepada pemberhentian dengan tidak hormat dari dinas TNI (pecat).

Menimbang: bahwa mengenai layak dan tidaknya terdakwa untuk tetap dipertahankan dalam dinas Militer, Majelis Hakim mengemukakan pendapat sebagai berikut (Bambang Sunggono, 2003):

a. Bahwa perbuatan terdakwa ini dapat membahayakan generasi muda Indonesia dan apabila dibiarkan maka akan berpengaruh besar terhadap keamanan dan kelangsungan umat manusia khusus di Negara Kesatuan Republik Indonesia.

b. Bahwa perbuatan Terdakwa ini sangat bertentangan dengan program pemerintah dalam pemberantasan narkotika.

c. Bahwa perbuatan Terdakwa ini juga sangat bertentangan dengan cita-cita dan keinginan dari Panglima TNI dalam membantu pemerintah memberantas narkotika dan juga prajurit TNI khususnya bersih serta terbebas dari pengaruh narkotika.

d. Bahwa perbuatan terdakwa ini merupakan salah satu dosa besar yang tidak dapat diampuni apabila dilakukan oleh seorang prajurit TNI karena sangat berbahaya bagi prajurit TNI lainnya apabila hal serta berpengaruh besar dalam pelaksanaan tugas sebagai prajurit TNI.

e. Bahwa berdasarkan alasan tersebut diatas, majelis hakim berpendapat bahwa terdakwa sudah tidak layak untuk tetap dipertahankan dalam dinas militer, oleh karenanya 
terdakwa harus diberikan hukuman tambahan pemecatan dari dinas militer.

\section{SIMPULAN}

Penerapan Asas Kepentingan Militer di Pengadilan Militer I-03/Padang sudah dapat berjalan dengan baik dan tidak mendapatkan kendala yang berarti hal mana didalam Putusannya majelis hakim Pengadilan militer II-03/Padang terhadap kasus tindak pidana narkotika yang dilakukan oleh prajurit di samping mempertimbangkan hal-hal memberatkan dan hal-hal meringankan hukuman juga mempertimbangkan asas kepentingan militer tidak secara eksplisit akan tetapi secara implisit. Putusan majelis hakim Pengadilan militer II-03/Padang terhadap kasus tindak pidana narkotika oleh prajurit TNI baik sebagai pemakai pemula maupun pecandu apalagi pengedar selalu mempertimbangkan asas kepentingan militer, dan selalu berujung kepada pemecatan (PDTH), namun didalam amar putusan tidak ada perintah kepada terpidana untuk dirahabilitasi setelah dipecat (PDTH).

\section{SARAN}

Disarankan kepada Majelis hakim Pengadilan militer II-03/Padang khususnya dalam hal menanggani kasus tindak pidana narkotika yang dilakukan oleh prajurit TNI, di samping mempertimbangkan hal-hal memberatkan dan hal-hal meringankan hukuman serta Kepentingan Militer, ke depan apabila majelis menghukum terdakwa dengan pidana penjara dan diikuti dengan hukuman tambahan pemecatan (PDTH), agar didalam putusannya terpidana diperintahkan untuk direhabitasi medis sebagaimana diamanahkan oleh pasal 54 Undang-Undang Nomor 35 Tahun 2009 Tentang Narkotika.

\section{UCAPAN TERIMA KASIH}

Disampaikan kepada ayah tercinta Umar Sutan Rumah Panjang (alm), ibunda Hj. Rosmi, Nain, istri tercinta dr. Gita Savina dan anak-anak tersayang Muhammad Ilham Gimulya, Azzahra Putri Gimulya, sebungsu Salsabila Nadhifa Gimulya serta kakak-kakak, adik-adik, Ipar, urang sumando penulis yang ikut memberikan semangat dan motivasi bagi penulis dalam menyeselaikan tesis ini. Penulis juga ingin mengucapkan terima kasih dan penghargaan yang sebesar-besarnya kepada: Bapak Prof. Dr. Zainul Daulay, S.H., M.H. selaku Dekan Fakultas Hukum Universitas Andalas beserta civitas akademika.

\section{DAFTAR PUSTAKA}

Bambang Sunggono, 2003, Metodologi Penelitian Hukum, PT. Raja Grafindo Persada, Jakarta.

Dilmil I-03/Padang, Laporan Tahunan, 2015, 2016, 2017.

Iman Syahputra Putra Tunggal, 1999, Undang-undang tentang Peradilan Nomor 31 tahun 1997 tentang Peradilan, Militer Harvindo, Jakarta.

Mario Sofia Nasution Antara sumbar, kamis 27 Juni 2017 jam10.15 Wib.

Panglima TNI, liputan 6, 27 Pebruari 201615.40 wib, diakses terakhir 
Jurnal Cendekia Hukum: Vol. 4, No 2, Maret 2019

pada 2 Pebruari 2018 Pukul 18.20 wib.

Oke zone.com. diunduh terakhir kali senin. 08 Januari 2018 jam .21 .48 Wib.
Spmad, 2017, Data rekapitulasi Gakkumplintatib/laka lalin. 